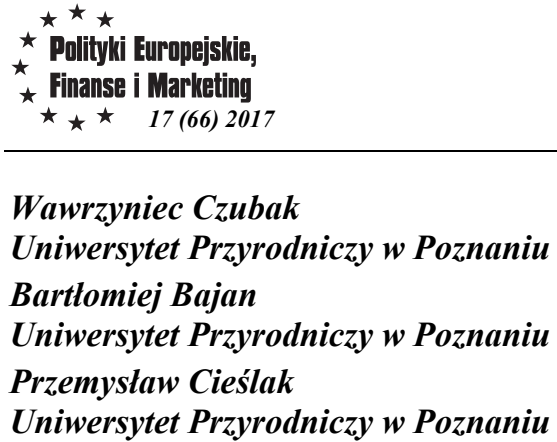

Wawrzyniec Czubak

Uniwersytet Przyrodniczy w Poznaniu

Bartlomiej Bajan

Uniwersytet Przyrodniczy w Poznaniu

Przemyslaw Cieślak

Uniwersytet Przyrodniczy w Poznaniu

\title{
Platności bezpośrednie dla rolnictwa w Polsce w warunkach pozostawania poza strefą euro
}

\section{DIRECT PAYMENTS FOR AGRICULTURE IN POLAND IN CONDITIONS OF STAYING OUTSIDE THE EURO AREA}

Celem opracowania jest oszacowanie skutków jakie dla polskich gospodarstw rolnych niesie za sobq pozostawanie poza uniq walutowa $w$ nawiqzaniu do systemu przeliczania płatności bezpośrednich dla krajów, które nie sq członkami strefy euro. Analiza skupia się na corocznych różnicach kursowych, pomiędzy wartościami referencyjnymi Europejskiego Banku Centralnego $(E B C)$, po których przelicza sie płatności bezpośrednie, a kursami z dni, w których wypłacane sa środki dla gospodarstw rolnych. Badaniu zostaly poddane wyptaty realizowane $w$ kampaniach 2005-2013.

$W$ analizowanym okresie rolnicy stracili na przeliczaniu płatności około 750 milionów złotych, co nie przekracza 1\% otrzymywanej pomocy. Niepokojqce moga być jednak krótkookresowe wahania kursowe, które w 2008 roku spowodowaty strate 25\% środków (ponad 2 miliardy złotych) $w$ stosunku do tego co uzyskaliby beneficjenci w przypadku uczestnictwa $w$ strefie euro.

Słowa kluczowe: strefa euro, płatności bezpośrednie, dochody rolnicze

\section{Wstęp}

W warunkach integracji europejskiej, rozwój polskiego rolnictwa zależy w znacznej mierze od transferów pieniężnych $\mathrm{z}$ budżetu krajowego oraz unijnego (Grzelak, Wiktorowicz 2009). Wejście w życie traktatu akcesyjnego oznaczało rezygnację z własnej polityki rolnej na rzecz Wspólnej Polityki Rolnej Unii Europejskiej (WPR), która jest jednym z kluczowych elementów działalności wspólnotowej. Wystarczy wspomnieć, że prawie $45 \%$ środków $z$ budżetu unijnego, przeznaczonych na perspektywę finansową 2000-2006 zostało wydanych na rolnictwo. Z kolei w perspektywie na lata 2007-2013 było to około 42\% (Russel 2012). Transfery środków finansowych $\mathrm{z}$ zagranicy związane są $\mathrm{z}$ ryzykiem kursowym, które można wyeliminować poprzez unifikację walut. W rolnictwie ryzyko to, poza handlem zagranicznym, jest szczególnie widoczne przy przeliczaniu płatności bezpośrednich w ramach uproszczonego systemu płatności obszarowych (SAPS) (Orłowski, Poczta 2013). Zmiana waluty prowadzi jednak do wywołania wielu innych efektów, głównie o charakterze makroekonomicznym, które w ostateczności wpływają na poszczególne sektory w tym także rolny. Nie można więc przeprowadzić rzetelnej analizy bez 
przyjrzenia się skutkom wprowadzenia wspólnej waluty, zawartym w teorii integracji walutowej. Należy przypomnieć, że Polska zobowiązała się przyjąć euro wraz z wejściem do Unii Europejskiej, jednak szczegółowa data przyłączenia się do strefy pozostaje nieustalona, co skłania do dyskusji na temat takiej decyzji.

\section{Teoria integracji walutowej}

Teorię integracji walutowej utożsamia się w literaturze przedmiotu z teorią Optymalnego Obszaru Walutowego (OOW). Po raz pierwszy, tego określenia użył R. Mundell (1961) definiując je jako region, w którym istnieje jedna lub kilka walut o ustalonym, sztywnym kursie względem siebie. Dopełnienia definicji dokonał H.G. Grubel (1970), który identyfikował OOW jako grupę krajów, dla których posiadanie wspólnej waluty związane jest $\mathrm{z}$ większą ilością korzyści niż strat, co przyczynia się do wzrostu dobrobytu na ich terenie.

Głównych, bezpośrednich korzyści wynikających z uczestnictwa w unii walutowej upatruje się w redukcji ryzyka kursowego, jak i redukcji kosztów transakcyjnych, z których wynika ożywienie wymiany handlowej, a także wzrost inwestycji krajowych i zagranicznych. Ponadto jako ewentualne, pozytywne efekty przystapienia Polski do strefy euro, wskazuje się na wzrost zaufania do polityki gospodarczej i stabilności pieniądza na arenie międzynarodowej oraz zwiększenie wpływu na decyzje podejmowane wewnątrz Unii Europejskiej. Wynika $\mathrm{z}$ tego, że profitów z członkostwa w unii walutowej należy się dopatrywać przede wszystkim w intensyfikacji wymiany handlowej oraz napływie inwestycji zagranicznych do kraju tworzącego OOW (Pietryka 2016).

Natomiast główne koszty integracji walutowej wiążą się z rezygnacją z własnej polityki pieniężnej i kursowej, które stanowią skuteczny mechanizm absorpcji wstrząsów zachodzących $\mathrm{w}$ gospodarce. W szczególności związane jest to $\mathrm{z}$ występowaniem szoków asymetrycznych, które są zakłóceniami charakteryzującymi się niejednakową siłą oddziaływania $\mathrm{w}$ gospodarkach poszczególnych członków unii walutowej (Borowski 2001). Liczne badania wskazują jednak na ograniczone i krótkotrwałe oddziaływanie kursu walutowego na wzrost konkurencyjności kraju poprzez dewaluacje waluty. W dłuższym okresie, działania takie powodują wzrost presji inflacyjnej (NBP 2010). W literaturze wskazuje się również na koszty organizacyjne i techniczne o charakterze krótkotrwałym, są to koszty jednorazowe i w dużej mierze ponoszone przez banki (centralny i komercyjne).

W związku z ujednoliceniem polityki fiskalnej i kursowej, nie mogą one stanowić skutecznego narzędzia redukcji szoków asymetrycznych we wszystkich krajach, które posiadają wspólny pieniądz. Zgodnie z teorią OOW, istnieje jednak wiele kryteriów, które potencjalnie zmniejszają prawdopodobieństwo występowania szoków. Można do nich zaliczyć (Jurek 2013):

- wysoki stopień synchronizacji cykli koniunkturalnych;

- wysoką mobilność czynników wytwórczych;

- wysoką elastyczność płac;

- integrację fiskalną i polityczną;

- podobieństwo stóp inflacji;

- dywersyfikację gospodarki w zakresie produkcji i konsumpcji;

- niską zmienność realnego kursu walutowego; 
W myśl wspomnianej teorii, im więcej z kryteriów zostaje spełnionych, tym mniejsza jest podatność na występowanie szoków asymetrycznych, natomiast, jeżeli wystąią, wzrasta zdolność do ich absorpcji. Perturbacje spowodowane niespełnianiem powyższych kryteriów, są możliwe do wyeliminowania jedynie poprzez kanał fiskalny, ponieważ wspólnotowa polityka pieniężna jest $\mathrm{w}$ stanie łagodzić jedynie szoki występujące w skali całej strefy. Wynika z tego, że skuteczna polityka antycykliczna na terenie poszczególnych krajów musi być prowadzona za pomocą polityki fiskalnej (NBP 2009).

W strefie euro, przesłanki teoretyczne odnoszace się do przeciwdziałania szokom asymetrycznym, zostały ujęte w kryteriach konwergencji nominalnej, które są warunkami, jakie musi spełniać państwo by zostać uznane za gotowe do uczestnictwa w unii walutowej. Ocenie podlega sytuacja finansów publicznych kraju oraz stabilność w zakresie stóp procentowych, kursu walutowego oraz cen. Dodatkowo brane są pod uwagę kryteria konwergencji prawnej, skupiające analizę zgodności ustawodawstwa krajowego o funkcjonowaniu Unii Europejskiej oraz Statut Europejskiego Systemu Banków Centralnych i Europejskiego Banku Centralnego (Żukrowska, Sobczak 2004). Ponadto utworzenie strefy euro poprzedzone było prawie 50-letnim okresem pogłębiającej się współpracy gospodarczej i politycznej. W tym czasie w państwach wspólnoty zostały wprowadzane kolejno: strefa wolnego handlu, unia celna oraz wspólny rynek, a ostatnim etapem integracji było wprowadzenie unii walutowej (Zamojska 2000). Ścisła współpraca gospodarcza przyczynia się do zbliżania cykli koniunkturalnych pomiędzy krajami, co zgodnie z teorią OOW zmniejsza ryzyko występowania szoków asymetrycznych.

Z syntetycznie przedstawionej teorii integracji walutowej wynika, że istnieje wiele pozytywnych przesłanek do tworzenia optymalnych obszarów walutowych, jednak proces ten, nie jest wolny od zagrożeń. W samej strefie euro położono nacisk na łagodzenie negatywnych efektów posiadania wspólnej waluty, co pozwala redukować możliwość ich wystąpienia. Przystępując do analizy skutków, które dla polskich gospodarstw rolnych niesie za sobą pozostawanie poza unią walutowa, w nawiązaniu do systemu przeliczania płatności bezpośrednich, należy mieć owe zależności na uwadze, pamiętając, że sama decyzja o przyjęciu euro musi być wypadkową jej wpływu na całą gospodarkę, a nie wyłącznie na jeden wybrany sektor.

\section{Sposób przeliczania płatności bezpośrednich w Polsce}

W związku z akcesją Polski do Unii Europejskiej w 2004r. wprowadzony został uproszczony system płatności obszarowych. Na podstawie powierzchni użytków rolnych przyznawane jest proporcjonalne wsparcie finansowe dla gospodarstw (niezależne od prowadzonej działalności rolniczej). Zgodnie z Ustawą z dnia 18 grudnia 2003 roku o płatnościach bezpośrednich do gruntów rolnych i oddzielnej płatności z tytułu cukru (Dz.U. $2004 \mathrm{nr} 6$ poz. 40 z późn. zm.), system płatności bezpośrednich składa się z dwóch elementów. Pierwszym $\mathrm{z}$ nich jest Jednolita Płatność Obszarowa (JPO), wypłacana do wszystkich użytków rolnych utrzymywanych w dobrej kulturze rolnej. Drugim elementem są Uzupełniające Płatności Obszarowe (UPO), wypłacane do powierzchni określonych roślin uprawnych. W związku z oceną funkcjonowania Wspólnej Polityki Rolnej w 2009 roku, dzięki zlikwidowaniu płatności powiązanych z 
produkcją i przekazaniu środków do systemu JPO, nastąpiło całkowite oddzielenie płatności od produkcji.

Płatności bezpośrednie od 2005 roku, zgodnie z art. 28 Rozporządzenia Rady (WE) nr 1782/2003 z dnia 29 września 2003 roku (z późn. zm.), wypłacane są począwszy od dnia 1 grudnia roku bieżącego do dnia 30 czerwca kolejnego roku kalendarzowego. Okres wypłat jest równoległy we wszystkich państwach Unii Europejskiej. W przypadku posiadania własnej waluty przez kraj członkowski UE, otrzymywane środki podlegają przeliczeniom według art. $45 \mathrm{ww}$. rozporządzenia, wedle którego państwa członkowskie dokonują przeliczania na walutę krajową na podstawie ostatniego kursu wymiany walut, przed dniem 1 października danego roku, ustalonego przez Europejski Bank Centralny. W Polsce Agencja Restrukturyzacji i Modernizacji Rolnictwa przed wypłatą środków w ramach WPR zaciaga w Ministerstwie Finansów pożyczkę w walucie krajowej na prefinansowanie płatności bezpośrednich. Następnie Komisja Europejska otrzymuje sprawozdania miesięczne $\mathrm{z}$ wypłat środków (w poprzednim miesiącu), wyrażone $\mathrm{w}$ euro po przeliczeniu według kursu ostatniego dnia września. Na podstawie sprawozdań, Komisja Europejska zwraca środki za zrealizowane wydatki. Równolegle Ministerstwo Rolnictwa i Rozwoju Wsi spłaca zobowiązania zaciągnięte przez ARiMR w kwotach równych ze zwracanymi środkami (Poślednik 2009).

\section{Skutki przeliczania płatności bezpośrednich w Polsce}

Każdego roku kurs z ostatniego dnia września, różni się od kursów z dni, w których gospodarstwa rolne otrzymują środki finansowe. W niektórych latach rolnicy odnoszą z tego powodu korzyści, a w innych straty. Wprowadzenie w Polsce euro spowoduje całkowitą likwidację tego zjawiska. Aby móc ocenić efekty przeliczania płatności bezpośrednich, należy przyjrzeć się kosztom utraconych korzyści, które ono za sobą niesie. Obliczenia dla lat 2009-2013 zostały wykonane na podstawie niepublikowanych danych ARiMR o kwotach zrealizowanych płatności w poszczególnych dniach. Na bazie tych danych ustalono jaki procent środków z I filara WPR był wypłacany średnio w konkretnym dniu w latach 2009-2013. Dla każdego dnia została ustalona indywidualna wartość (na przykład, pierwszego dnia wypłat do rolników trafia 5,47\% wszystkich środków). Na tej podstawie sporządzono obliczenia szacunkowe dla lat 2005-2008. W tabeli 1 przedstawiono, jakie wsparcie $\mathrm{w}$ ramach płatności bezpośrednich zostało przekazane rolnikom w kampaniach 2005-2013, oraz jakie wsparcie otrzymaliby w analogicznym okresie, gdyby Polska należała do strefy euro. 
Tabela 1. Skutki przeliczania płatności bezpośrednich dla rolnictwa $\mathrm{w}$ Polsce $\mathrm{w}$ kampaniach 2005-2013 (kwoty w PLN)

\begin{tabular}{|c|c|c|c|}
\hline kampania $^{1}$ & $\begin{array}{l}\text { wartość płatności bezpośrednie } \\
\text { po przeliczeniu według kursu } \\
\text { EBC z dnia } 30 \text { września }\end{array}$ & $\begin{array}{c}\text { wartość płatności bezpośrednich } \\
\text { w przypadku uczestnictwa } \\
\text { Polski w strefie euro }\end{array}$ & $\begin{array}{c}\text { zysk/strata } \mathrm{z} \text { tytułu braku } \\
\text { uczestnictwa w strefie } \\
\text { euro }\end{array}$ \\
\hline 2005 & 6692166292,04 & 6557450260,10 & 134716031,94 \\
\hline 2006 & 8202448694,01 & 7974626125,59 & 227822568,42 \\
\hline 2007 & 8280978582,78 & 7857702393,93 & 423276188,85 \\
\hline 2008 & 8588710412,97 & 10798492944,21 & $-2209782531,24$ \\
\hline 2009 & 12150501851,26 & 11715574512,94 & 434927 338,32 \\
\hline 2010 & 12582238903,64 & 12505124539,46 & 77114364,18 \\
\hline 2011 & 14138583370,06 & 13913325935,57 & 225257434,49 \\
\hline 2012 & 13732861625,51 & 13932351436,12 & $-199489810,61$ \\
\hline 2013 & 14117155347,68 & 13975239648,02 & 141915699,66 \\
\hline suma & 98485645079,95 & 99229887795,95 & $-744242716,00$ \\
\hline
\end{tabular}

Źródło: Opracowanie własne na podstawie danych ARiMR z dnia 31.12.2014 roku o kwotach zrealizowanych płatności w poszczególnych dniach kampanii.

W sumie od kampanii 2005 do 2007 rolnicy w Polsce zyskali, na braku uczestnictwa $\mathrm{w}$ strefie euro z tytułu płatności bezpośrednich prawie $800 \mathrm{mln}$ zł, co jest równowartością około 3,3\% otrzymanych w tym czasie środków. Jednak już w samej kampanii 2008 strata $\mathrm{z}$ tego samego tytułu wyniosła więcej niż 2,2 mld zł i było to ponad $25 \%$ kwoty uzyskanej w ramach płatności bezpośrednich w tym okresie. W kampaniach 2009-2013 rolnicy zyskali na systemie przeliczania blisko $700 \mathrm{mln}$ zł. Jednak z racji znacznego zwiększenia się ilości środków przeznaczanych na dopłaty w tym czasie w Polsce, było to jedynie około 1\% wszystkich funduszy uzyskanych na ten cel z Unii Europejskiej. W całym badanym okresie (kampanie 2005-2013), Polscy rolnicy stracili, z powodu braku przynależności Polski do strefy euro, z tytułu płatności bezpośrednich prawie $750 \mathrm{mln}$ zł. Jest to jednak zaledwie około $0,75 \%$ wartości wszystkich uzyskanych środków pomocowych w kampaniach 2005-2013.

Ponadto, dane ARiMR wykazują, że średnio prawie 30\% środków trafiało do gospodarstw rolnych już w pierwszym miesiącu wypłat. Z kolei do końca stycznia na kontach rolników znajdowało się około $60 \%$ kwoty przeznaczonej na płatności bezpośrednie. Dokładnie w połowie okresu, w którym odbywał się transfer środków pomocowych w analizowanych kampaniach, rozdysponowane było średnio ponad $87 \%$ $\mathrm{z}$ nich. Wskazuje to na wyższe znaczenie kursów walutowych w początkowych miesiącach wypłacania płatności bezpośrednich.

Pomimo, iż w badanym okresie strata dla gospodarstw rolnych nie przekraczała $1 \%$, to wahania w wysokości dopłat sięgające nawet do $25 \%$, mogą mieć istotny wpływ

\footnotetext{
${ }^{1}$ Kampania obejmuje okres od 1 grudnia do 30 czerwca. Dla przykładu kampania 2005 obejmuje wypłaty od grudnia 2005 roku do końca czerwca 2006 roku (dodatkowo w ciągu roku wypłacane są również środki wynikające z zaległości lub innych rozstrzygnięć, wcześniej składanych wniosków).
} 
na kondycję finansową gospodarstw rolnych. Wynika to $\mathrm{z}$ faktu, że płatności bezpośrednie mają duże znaczenie dla dochodów osiaganych przez gospodarstwa rolne w Polsce. Dane dotyczące udziału płatności bezpośrednich w dochodach rolniczych przedstawiono w tabeli 2 .

Tabela 2. Udział płatności bezpośrednich w dochodach rolniczych w latach 2005-2013 (kwoty w PLN)

\begin{tabular}{|c|r|r|r|}
\hline rok & $\begin{array}{c}\text { wartość zrealizowanych } \\
\text { płatności bezpośrednich }\end{array}$ & dochody rolnicze & $\begin{array}{c}\text { udział płatności } \\
\text { bezpośrednich w } \\
\text { dochodach rolniczych (\%) }\end{array}$ \\
\hline 2005 & 6692166292 & 18400000000 & 36,4 \\
\hline 2006 & 8202448694 & 20589600000 & 39,8 \\
\hline 2007 & 8280978583 & 25410400000 & 32,6 \\
\hline 2008 & 8588710413 & 21620000000 & 39,7 \\
\hline 2009 & 12150501851 & 24269600000 & 50,1 \\
\hline 2010 & 12582238904 & 28446400000 & 44,2 \\
\hline 2011 & 14138583370 & 32991200000 & 42,9 \\
\hline 2012 & 13732861626 & 30470400000 & 45,1 \\
\hline 2013 & 14117155348 & 33340800000 & 42,3 \\
\hline suma & $\mathbf{9 8 4 8 5 6 4 5 0 8 0}$ & $\mathbf{2 3 5 5 3 8 4 0 0 0 0 0}$ & 41,8 \\
\hline
\end{tabular}

Źródło: Opracowanie własne na podstawie Polska wieś 2014. Raport o stanie wsi oraz EUROSTAT.

Średni udział środków z płatności bezpośrednich w dochodach rolniczych w latach 2005-2013 wynosił prawie 42\%. Od roku 2009, w którym nastąpił wyraźny, wartościowy wzrost płatności bezpośrednich $\mathrm{z}$ około 8,5 mld złotych w roku poprzednim, do ponad 12 mld złotych, udział w dochodach rolniczych nie spadł poniżej 40\% aż do końca analizowanego okresu. Różnice kursowe z 2008 roku, które miały wpływ na spadek realnej wartości uzyskanych dopłat aż o $25 \%$, spowodowały zmniejszenie się dochodów rolniczych o ponad $9 \%$. ${ }^{2}$ Jest to znaczący odsetek, zwłaszcza że zależy jedynie od wahań kursowych. W 2013 roku w stosunku do 2005 roku, dochody rolnicze wzrosły o około $45 \%$, przy średnim tempie zmian na poziomie $7,1 \% \mathrm{z}$ kolei wartość płatności bezpośrednich wzrosła o około 53\%, przy średnim tempie zmian wynoszącym $10 \%$. Stąd dla początkowych lat, udział płatności w dochodzie jest niższy niż w latach późniejszych. Potwierdzeniem dla wysokiego znaczenia płatności bezpośrednich dla dochodów rolniczych jest współczynnik korelacji dla tych dwóch cech, który wynosi 0,91 . Wskazuje to na silną zależność pomiędzy obiema cechami, co przy tak wysokim udziale dopłat $\mathrm{w}$ dochodach gospodarstw rolnych, jest rzeczą naturalną.

\footnotetext{
${ }^{2}$ Biorąc pod uwagę jedynie samą kwotę dopłat, bez ewentualnych korzyści, które mogły odnieś gospodarstwa rolne z tytułu posiadania większej ilości środków pieniężnych.
} 


\section{Podsumowanie}

Biorąc pod uwagę, że oszacowane, niekorzystne relacje z tytułu systemu przeliczania płatności bezpośrednich dla rolnictwa w kampaniach 2005-2013, nie przekraczają 1\% wartości wszystkich otrzymanych środków, należy sądzić, że nie ma to istotnego wpływu na kondycję finansową gospodarstw. Wniosek ten uzasadnia również fakt, że w większości lat system okazał się nawet korzystniejszy, niż byłoby to w przypadku uczestnictwa w strefie euro. Kluczowe znaczenie, mają jednak poziomy wahan kursowych, które zazwyczaj powodują kilkuprocentowe różnice pomiędzy wartościami środków wypłacanych po kursie referencyjnym z ostatniego dnia września, w stosunku do ich realnych wartości z dnia wypłaty. Skrajny przypadek zaistniały w 2008 roku, spowodował „straty” w wysokości $25 \%$ otrzymanych płatności bezpośrednich, co w połączeniu z dużym ich znaczeniem dla dochodów rolniczych spowodowało utratę prawie $10 \%$ całości dochodów, wypracowanych w gospodarstwach rolnych.

Na podstawie powyższych wniosków należy sądzić, że przystąienie Polski do strefy euro przyniosłoby wymierne korzyści dla rolnictwa, a przede wszystkim wpłynęłoby wprost na wyeliminowanie ryzyka kursowego. Jednak decyzja o utworzeniu optymalnego obszaru walutowego nie może zostać podjęta w oparciu o analizę skutków dla jednego problemu, czy nawet całego sektora. Powinna opierać się na podejściu całościowym do problemu i uwzględniać w szczególności przesłanki zawarte w teorii integracji walutowej, jak również obecną sytuację makroekonomiczną.

\section{Bibliografia}

Borowski J.: Podatność Polski na szoki asymetryczne a proces akcesji do Unii Gospodarczej $i$ Walutowej. „Bank i Kredyt”, Nr 11-12, 2001.

Grzelak M., Wiktorowicz J.: Ocena wsparcia publicznego rolnictwa w Polsce - wybrane zagadnienia. Zeszyty Naukowe SGGW w Warszawie - Problemy Rolnictwa Światowego, t. 7(22), 2009.

Grubel H.G.: The Theory of Optimum Currency Areas. „Canadian Journal of Economics”, Vol. 3, No. 2, 1970.

Jurek M.: System kursów walutowych krajów Europy Środkowo-Wschodniej oraz zmienność kursów ich walut względem euro. „Ekonomista”, Nr 2, 2013.

Mundell R.: A Theory of Optimum Currency Areas. „American Economic Review”, Vol. 51, No. 4, 1961

NBP: Raport na temat petnego uczestnictwa Rzeczypospolitej Polskiej w trzecim etapie Unii Gospodarczej $i$ Walutowej. Warszawa, 2009.

NBP: Mechanizmy funkcjonowania strefy euro, Teoretyczne podstawy integracji walutowej. Warszawa, 2010.

Nurzyńska I., Poczta W. (red.): Polska wieś 2014, raport o stanie wsi. Wydawnictwo Naukowe Scholar. Warszawa, 2014

Orłowski W., Poczta W.: Czy Polska powinna przyjać Euro? Potencjalne skutki dla rolnictwa i obszarów wiejskich. Warszawa, 2013.

Pietryka I. (red.): Makroekonomiczne skutki wprowadzenia euro w Polsce w świetle doświadczeń innych państw. Problemy Gospodarki Światowej, tom VI. Polskie Towarzystwo Ekonomiczne Oddział w Toruniu, Instytut Badań Gospodarczych. Torun, 2016.

Poślednik A.: Wplyw kursu euro na wysokość płatności bezpośrednich. FAPA. Warszawa, 2009. 
Rozporządzenia Rady (WE) nr 1782/2003 z dnia 29 września 2003 roku ustanawiające wspólne zasady dla systemów wsparcia bezpośredniego w ramach wspólnej polityki rolnej i ustanawiające określone systemy wsparcia dla rolników

Russel P.: Ewolucja wieloletnich ram finansowych Unii Europejskiej. „Studia BAS”, nr 3(31), 2012.

Ustawa z dnia 18 grudnia 2003 r. o płatnościach bezpośrednich do gruntów rolnych i oddzielnej płatności z tytułu cukru (Dz.U. 2004 nr 6 poz. 40 z późn. zm.)

Zamojska A.: Unia Gospodarcza i Walutowa, SGGW, Warszawa, 2000

Żukrowska K., Sobczak D.: Perspektywy uczestnictwa Polski w Unii Gospodarczo-Walutowej, SGH, Warszawa, 2004.

\section{Summary}

The purpose of the study is to demonstrate the effects that, for Polish farmers, entails staying out of the monetary union in relation to the conversion system of direct payments for countries that are not members of the euro zone. The analysis focuses on yearly differences between the reference values of exchange rate of the European Central Bank (ECB), which are the base for direct payments conversion and daily exchange rates in which the funds are paid to farmers. The analysis covers the payment campaigns 2005-2013. In the analysed period, farmers lost on the conversion of payments about 750 million zlotys, which does not exceed $1 \%$ of the received aid. The worrying fact however, may be short-term fluctuations of exchange rate, which in 2008 resulted in a loss of $25 \%$ (more than 2 billion zlotys) in relation to what beneficiaries would receive in case of participation in the euro zone.

Key words: euro area, direct payments, agricultural income

\section{Adres do korespondencji:}

\section{dr hab. Wawrzyniec Czubak}

Katedra Ekonomii i Polityki Gospodarczej w Agrobiznesie

Wydział Ekonomiczno-Społeczny

Uniwersytet Przyrodniczy w Poznaniu

ul. Wojska Polskiego 28

60-639 Poznań

e-mail: czubak@up.poznan.pl 